\title{
CITIZENSHIP CEREMONIES IN GERMANY: A MORE UNIVERSALIST KULTURNATION
}

\author{
Maria Jakob ${ }^{1}$ \\ Leipzig University
}

\begin{abstract}
After 2000, a profound liberalization of naturalization criteria in Germany was followed by culturalist setbacks: language requirements were tightened, a civics test, a pledge of allegiance, and citizenship ceremonies were introduced. Can these developments be termed a liberal assimilationist turn in what it means to be a citizen or is this a revival of the old notion of a German cultural identity as Kulturnation (cultural nation)? The qualitative study of German citizenship ceremonies presented herein, provides an in-depth analysis of the logics of "liberal assimilation" and the nexus between culture, citizenship, and national belonging. At the ceremonies, "culture" is referenced as a universally human feature that binds people together. Conversely, culture is also presented as an individual folkloristic asset that can be used for profit and for contributing to the value of diversity. This twofold conceptual specification of "culture" is then discussed as an adaptation of the originally universalist Kulturnation idea and as a modern solution to the problem of societal integration.
\end{abstract}

\footnotetext{
${ }^{1}$ Maria Jakob holds a Magister Degree in Political Science and Cultural Studies. She has obtained a PhD in Cultural Sociology with a study about Naturalization Ceremonies in Germany in 2016 and is currently working as a research assistant at the Institute for the Study of Culture at Leipzig University.
} 


\section{Introduction}

The nexus between culture and citizenship is one of the central variables when it comes to determining the character of a country's citizenship model or national model of belonging. In the context of citizenship regulations, "culture" is most commonly understood as the language, religion, and customs of the majority or major parts of society, to which citizenship candidates must conform. This understanding of "culture" is clearly regulated and tested in terms of language skills. However "culture" is hard to operationalize and fiercely discussed when it comes to customs or religious practices, as has become visible in the debates about the face-veil at Canadian citizenship ceremonies ${ }^{2}$, and about the Islamic headscarf in German public schools and administration (Joppke 2007; Korteweg and Yurdakul 2015).

German citizenship law and the country's understanding of nationhood were long perceived as based on cultural and ethnic homogeneity. Germany's citizenship regulations have been based on an exclusive understanding of membership for the majority of $20^{\text {th }}$ century, leading Rogers Brubaker to his characterization of the German understanding of nationhood as "ethnocultural" and "differentialist" (1992, 3). Contrasting Germany with the rather "state-centered" and "assimilationist" French model, Brubaker updated the typology of Prussian historian Friedrich Meinecke who in 1908 already termed Germany a cultural nation ("Kulturnation") in contrast to the French political nation ("Staatsnation") (1970, 11-22). However, there has been notable immigration to Germany since the 1960s. This can be treated as a latent, long-term crisis of the country's pre-war citizenship configuration and modes of collective identity construction. This "migration-membership-dilemma" (Triadafilopoulos 2012, 1) called for political as well as discursive action. Consequently, there has been much discussion about citizenship and the status of Germany as a "non-immigration country" since the 1990s. From 2000 on, discussions in politics and the media about a German Leitkultur have risen. Literally translated as "leading" or "guiding culture", Leitkultur was the heart of a debate about whether there are certain elements of "German" culture existed which immigrants adopt for successful assimilation. While conservatives advanced the view of a homogenous German Volk ("people"), whose language, history, and religion should form a non-negotiable basis for future immigration and integration policies, liberal and social democrat forces viewed Leitkultur as a more universal humanist principle shaped by European values and experiences (see Klusmeyer 2001, Manz 2004, Pautz 2005).

Substantial reforms were also made to the citizenship law and naturalization procedures. When Rogers Brubaker asked about a "return of assimilation?" in 2001, naturalization in Germany had just been liberalized and elements of the birthplace principle (ius soli) had been introduced into citizenship law (Faist and Triadafilopoulos 2006; Green 2000). Brubaker thus reviewed his prior assessment of German citizenship law as "ethnocultural" and described the new German policies as "politically recognizing, legally constituting, and symbolically emphasizing commonality rather than difference" $(2001,539)$. Brubaker explicitly did not assess German citizenship policy as assimilationist in a strict sense, and at this time indeed the naturalization process did not

\footnotetext{
${ }^{2}$ See The Guardian, "Canada to press for ban on Islamic veil at citizenship ceremonies", September 16, 2015; http://www.theguardian.com/world/2015/sep/16/canada-government-islamic-veil-niqab-ban-citizenship (accessed on 05-11-2017).
} 
contain any elements that aimed at a cultural assimilation of prospective German citizens. ${ }^{3}$ Such elements, however, were introduced only few years later. In 2007, the criteria for citizenship acquisition was amended and tightened: language requirements became stricter and more precise, a civics test and a compulsory pledge of allegiance (feierliches Bekenntnis) to the constitution were included in the application procedure. ${ }^{4} \mathrm{With}$ this last provision, citizenship ceremonies in Germany proliferated even though they are not a mandatory part of the naturalization process.

My aim in this article is to analyze the nexus between culture and citizenship in contemporary Germany. Can these recent developments be interpreted as a return to the idea of a Kulturnation, or have we witnessed an assimilative turn in what it means to be a German citizen? In the following section, I will contrast some assessments of recent developments in German citizenship law with the historic ideas of Kulturnation and Bildungsbürgertum ("educated bourgeoisie"), that continue to frame the discourse on German citizenship. I then turn to an indepth analysis of the speeches made at German citizenship ceremonies where "culture" is simultaneously depicted as a distinct and folkloristic feature of the immigrants, while also as a universal ground for belonging as cultivated subjects and citizens. In conclusion, this twofold depiction of culture will be discussed as a specific adaptation of the idea of Kulturnation, and presented as a possible solution to the challenge of diversity versus homogeneity in modern societies more broadly.

\section{German citizenship policy since 2000: Liberal assimilation or return of the Kulturnation?}

The liberalization of citizenship provisions in 2000 and ensuing introduction of language requirements, citizenship tests, the pledge of allegiance and the citizenship ceremonies, have been perceived as a moralization of citizenship by some scholars, and as a progression towards a civic conception of citizenship by others. Mathias Bös and Veronika Schmidt (2012) treat the introduction of a citizenship test in Germany as a "culturalization" of citizenship. They point out that there is a shift from an attributive understanding of ethnicity towards a more open conception where being a citizen and belonging can be learned and acquired. This "culturalization", and a parallel economization of citizenship - citizens as investments into the state's human capital - have resulted in a "moralization" of citizenship. Values and the active role of the citizens are emphasized, citizenship is not a mere status anymore. ${ }^{5}$ In contrast, Per Mouritsen describes the developments as a "republican normalization" (insert citation) in Germany, which approximates the country's citizenship regulations with those of France and the Netherlands. He upholds, however, that "Germany still presupposes a unified community of

\footnotetext{
${ }^{3}$ Before 2007, the only criteria for naturalization in Germany that could be interpreted as "cultural" was a written declaration of loyalty to the constitution and sufficient "knowledge of the language".

${ }^{4}$ Green (2012) offers a full analysis of the reforms on German citizenship law after 2000. The development of citizenship tests in Germany begins with a clearly anti-Muslim "interview guide" in the state of Baden-Württemberg (2006) and ends with the national version of 2007 which Michalowski $(2011,764)$ characterises as "relatively thin and procedural".

${ }^{5}$ Similarly, Willem Schinkel and Friso van Houdt (2010) describe a western European trend to moralizing citizenship. Yngve Lithman (2010) agrees with this diagnosis and in addition describes this trend as "cultural essentialization".
} 
culture and language, although the latter, crucially, has become transformed in a civic direction" (Mouritsen 2013, 90).

A peculiar combination of cultural unity and diversity seems to be at play here which has received different labels in scholarly research. Triadafilopoulos (2011) calls it 'civic integrationism' or 'Schmittian liberalism', Tebble (2006) speaks about 'identity liberalism', Fekete (2006) even opts for 'enlightened fundamentalism'. Perhaps most precisely, Christian Joppke (2008) has addressed this configuration as "the paradox of universalism". He states a renewed emphasis on the identity aspect of citizenship while its importance concerning status and rights seems to be declining (Joppke 2010b). However, because it is now impossible for western European states to refer to "national cultures", they instead promote ideas of 'constitutional patriotism' or 'political liberalism' (Joppke 2008, 536). Concerned by the dilemma of a particularistic identity that is deemed necessary for integration yet that cannot be supplied by a law or policy that must remain formally non-discriminatory, contemporary states are inclined to call a certain idea of liberalism to the rescue (ibid, 543-544). In so doing, liberalism is not treated as a formalistic, procedural societal feature. Instead, it is turned into an identity and connected with the idea of a shared way of life. So this is what Joppke (2008) comes to call the 'paradox of universalism': liberalism acted out in almost illiberal ways. ${ }^{6}$

While Joppke (2008) already delivers a pointed assessment of the nexus between culture and citizenship in German naturalization law after 2000, his argument is solely based on the legal provisions for naturalization. The contents and discourses which the new components of the procedure-namely the test and the ceremonies-include, are not taken into account. Furthermore, it is worth taking a step back to assess the ways in which the paradox stated by Joppke (2008) unfolds and even proves functional. For starters, the diagnosis of a 'culturalization' of citizenship, is quite broad and open to multiple interpretations as a result. Since concept of 'culture' can mean many different things, it follows that a culturalization of citizenship in an immigrant society can take many different shapes. There are at least two different dimensions of what 'culture' means. ${ }^{7}$ First, the concept may refer to a general characteristic of a society, homogenizing differences within 'German culture' or it could refer to a more tightly confined 'realm of culture' within a society depicting, for example, the fields of music, literature, arts and education as opposed to the political or economic fields. Second, "culture" may be perceived as something that shapes and even determines individual actions and values, or it could be seen as a merely superficial level of individual life such as eating habits or clothing preferences. The latter was similarly described by Herbert Gans (1979) as "symbolic ethnicity". With this term Gans aimed at a description of how descendants of European immigrants to the United States, while

\footnotetext{
${ }^{6}$ Similarly: Triadafilopoulos (2011). In a later article, Joppke (2010b) describes the paradox in slightly different terms concerning how new citizens (and citizens in general) are addressed: They are on the one hand "neoliberally" responsibilized and individualized, on the other hand they are required to assimilate into liberalism. In order to explain the contradiction between these two aims, Joppke again refers to the declining formal importance of citizenship: As "citizenship light" and as mere identity politics with low impact, the citizenship discourse can mirror the ambiguities of general discourses on belonging without much consequences.

${ }^{7}$ Andreas Reckwitz $(2008,19)$ also lists four conceptualizations of "culture": a normative, a collectivist, and a differentialist notion as well as a very general notion that associates culture with social meaning. While the notions he describes as collectivist and differentialist can be related to the first dimension in my account, his normative and meaning-related notions apply more to scientific conceptualizations of culture than to everyday or political discourses.
} 
being fully integrated and assimilated structurally, still identify with or practice "ethnicity". Instead of treating this phenomenon as an ethnic revival, Gans describes it as "a nostalgic allegiance to the culture of the immigrant generation (...), a love for and a pride in a tradition that can be felt without having to be incorporated in everyday behaviour" (Gans 1979, 9).

Accordingly, a culturalization of citizenship could point to an emphasis of common values, language and religion, as indicated in the 'moralization' diagnosis by Bös and Schmidt (2012) and the 'liberal assimilation' thesis by Joppke (2008), or to the promotion of knowledge about culture-as-arts. It could indicate a shift towards an exclusivist coupling of citizenship and culture-as-identity, or it could mean that culture-as-folklore may be actively promoted as something valuable within society. Therefore it is important not to just label the developments at hand but to analyze what the 'culturalization of citizenship' really means and encompasses in greater detail.

Also, the diagnosis of a culturalization of citizenship has to be placed within the historic context of ideas about German nationhood and citizenship. The debates rely on the underlying assumption that Germany has long been a Kulturnation when it comes to determining the basis of its citizenship law and its national identity. There also seems to be a broad agreement that the idea of a Kulturnation and its ethno-cultural determination of who can be a German citizen has been thoroughly discredited after the Nazi era (Levy 2002). Thus, if there is or has been a renewed culturalization of German citizenship or a revival of the idea of Kulturnation, this requires some explanation and a detailed analysis of what kind of culture and what kind of assimilation are at play. In order to adequately grasp the idea of Kulturnation and its contemporary influences, I briefly review its distinctive elements and their development. Specifically, I argue that its "ethnic" and its "cultural" elements must be considered separately.

According to Brubaker (1992), the German nation is fundamentally a Kulturnation, a nation based on a common culture rather than on a unified state. Historically, he traces the roots of this understanding to the first half of the $19^{\text {th }}$ century, when Germany was divided into a number of petty states and could only be imagined as a whole in terms of language and culture. Brubaker here refers to the Romantic movement which he presents as having laid the grounds of the "ethnocultural understanding of nationhood" (ibid, 9). Brubaker omits, though, that this conceptualization was only an advancement of a more universalist idea of Kulturnation which had been formulated earlier and did not yet encompass an ethnic notion of culture. As Bernhard Giesen (1999, 158-166) explains in his historic analysis of the "codes of collective identity" proliferated by German intellectuals, the idea of the Kulturnation was indeed developed in order to establish a basis for national belonging without a unified state in the early $19^{\text {th }}$ century. However the original version of Kulturnation can be attributed to the Bildungsbürgertum (intellectual bourgeoisie) and the context of the Enlightenment. The Bildungsbürgertum, which was the influential intellectual elite of the time, imagined a Kulturnation that - following the ideas of Goethe and Schiller - was based on the value of education, on intellectual achievement, as well as on individual virtue and aesthetic pursuit of the fine arts. In contrast to France, where at the same time political revolution was the means of introducing democracy and human rights, German intellectuals were preaching cultural refinement. Education should enable the people to fulfill their human potential, to become "truly free" (Münkler 2009, 340-341). "Culture" thus was more a general program than a mode of differentiation. Only later were these universalist ideas coupled with the idea of the Volk ("the people") and a distinctive Volksgeist ("spirit of the 
people") by the Romantic movement, reformulating the notion of the Kulturnation from 'culturally universalist' to 'ethno-culturally differentialist' (Giesen 1999, 271).

Against this background, the recent developments in German citizenship law with its focus on "liberal assimilation", language acquisition, and moral conduct could be described as a revival of the old, original conceptualization of the Kulturnation as a community of cultured and civilized citizens. However, the mere existence of citizenship tests and ceremonies can only indicate an overall tendency towards such a culturalization of citizenship. To analyze the link between culture and citizenship, its logics and its elements, we need to take into account how "culture" and different forms of cultural assimilation are presented and debated within the process of naturalization, the citizenship test and the ceremony. Specifically I chose to analyze the citizenship ceremonies as they offer the most profound insight into the various discourses and positionings of the relation between culture and belonging as a citizen. This can be attributed to their character as decentralized, non-standardized, complex, and multi-faceted events. As the idea of Kulturnation has oscillated between a universalist and an exclusivist and differentialist notion, the idea of "culture" used in the ceremonies also shows both of these aspects. In the data presented below, these two notions appear in metaphoric and narrative form. On the one hand, "culture" is presented as a feature that is possessed by every human being, in the basic ability to aesthetically perceive and perform visual or musical art. On the other hand, "culture" is dealt with as a key to understanding or integrating into a society, referring to the cognitive acquisition of knowledge about a body of literature and arts that is framed as nationally characteristic. Accordingly, the new citizens are also to addressed to some extent as representatives of their "home cultures", which are imagined in a folkloristic way. This two-fold conceptualization of "culture" as universalist but also as particular, offers an insight into the logics and mechanisms of the seemingly paradoxical claim of "liberal assimilation", which appears here as a paradox and also as a specific solution to the problem of how to discursively reconcile cultural unity and diversity.

\section{Citizenship Ceremonies in Germany}

Citizenship ceremonies have been introduced in several western European and American countries as well as in Australia to ritually celebrate the naturalization of new citizens. In scholarly research, the ceremonies have been evaluated as controlling and discriminatory against new citizens. ${ }^{8}$ However my goal herein is to consider the ceremonies as representative of wider societal practices and discourses, rather than focusing on their direct social function. I treat citizenship ceremonies as an indicator of how citizenship, societal identity and the new citizens are imagined and presented publicly. In this, I follow Tine Damsholt who has emphasized the ceremonies' expressive nature.

The citizenship rituals act as seismographic spaces, where national interest, emotions, xenophobia, and politics of belonging and integration surface and are negotiated and performed. Thus, Citizenship ceremonies form a kind of laboratory for articulating and materializing these new forms of belonging in all their ambiguity and heterogeneity $(2009,18)$.

\footnotetext{
${ }^{8}$ See Merelman (1988) for an analysis of the US ceremonies; Fassin and Mazouz (2009) for an analysis of France's ceremonies; and Verkaaik (2010) on the ceremonies of the Netherlands.
} 
In Germany, citizenship ceremonies can be seen as even more indicative of societal discourses and practices. Since the ceremonies only began to spread in 2007-following the introduction of a pledge of allegiance into the naturalization procedure - they are 'recently invented traditions'. 9 Therefore, the ceremonies have no fixed program or content and are neither imposed by federal administration nor institutionalized through tradition. The organizers and hosts of the ceremonies must come up with the ceremonial agenda and content individually, and thus will likely reflect broader societal discourses and practices of belonging and include them in the ceremonial framing.

Today, most of the naturalization ceremonies in Germany are organized by city administrations, in addition to ceremonies held at the district or federal state (Länder) levels. The ceremonies feature speeches from both administration officials - mostly city mayors - and naturalized women or men. The national anthem is sung, there is music, and some refreshments are offered. Curiously the pledge, which was the very reason for the proliferation of the ceremonies in the first place, is not always included. Many administrations prefer to carry out the pledge and the distribution of naturalization certificates individually, and then organize an additional common ceremony for all new citizens instead once or twice a year.

The following analysis is based on a data sample that consists of approximately 95 manuscripts of speeches from citizenship ceremonies from all over Germany, as well as of participant observation data from fourteen ceremonies held between 2010 and $2013 .{ }^{10}$ A selection of the manuscripts and processes were interpreted in depth using sequential analysis adapted from Ulrich Oevermann's objective hermeneutics methodology (Maiwald 2005; Oevermann et al. 1987). By analyzing the data line by line and even word by word, the contingency and selectivity of the statements or actions can be carved out against other possible options. This in turn allows for us to determine the underlying meaning and structure of the selections made. In my analysis I also follow Rudolf Schmitt's instructive focus on the analysis of metaphors (2005). His approach of collecting, sorting, and interpreting the set of metaphoric speech contained in a text helped me identify the centrality of the metaphoric concept of 'culture as a key' at the ceremonies. The overall theorization of the data was achieved following Grounded Theory methodology (Corbin and Strauss 2008, Strauss 1996), which also guided the Theoretical Sampling process of my data collection.

While my sole aim here is a thorough description of the mechanics of the seemingly 'paradoxical' issue of liberal or cultural assimilation, citizenship ceremonies are of course a specific occasion and the discourses and practices found herein cannot be generalized to the realm of everyday life. Thus, although citizenship ceremonies can be used to gain insight into politics and discourses of belonging and integration, it has yet to be determined how widespread and deeply rooted the assumptions about culture and ideas about cultural belonging found in the data presented here really are.

\footnotetext{
${ }^{9} \mathrm{I}$ am borrowing and adapting the concept proposed by Hobsbawm and Ranger (1983).

10 The data was collected as part of a larger ethnographic study on the proceedings and contexts of "doing belonging" at German citizenship ceremonies.
} 


\section{The mechanisms of 'liberal assimilation': Cultural practice and humanity, folk culture and utility}

What happens at the citizenship ceremonies is a certain framing of belonging and of 'the citizen'. The new citizens are addressed individually: as subjects who are learning, who are professing their allegiance, and who are receiving some (limited) public attention as well as their certificates. Altogether, four distinct themes of how citizenship and belonging are framed at the German citizenship ceremonies emerged from my analysis. First, given that the ceremonies are hosted by cities or local districts, it is not surprising that local integration and identification are central, not national belonging. This theme permeates German ceremonies and helps local officials to evade ethnic definitions of citizenship. Second, the motive of individual confession is not only present in the pledge of allegiance, but also in the presentation of individual faces, biographies, and life plans. This theme aims at de-securitizing new citizens in the public eye through transparency and symbolic commitment. Third, individual economic efforts are presented as a basis for social recognition and the new citizens' economic success is narrated as a way to focus on the beneficial nature of immigration for German society. In this paper, I focus on the fourth main theme that appears at the ceremonies: 'universal culturalization'. This does not imply that the other themes have nothing to do with or even contradict the notion of liberal assimilation. Rather, all four themes are intertwined in what the new citizens are supposed to assimilate to and also what liberalism means at the ceremonies. However, the theme of 'universal culturalization' provides the most instructive and in-depth insight into the mechanics and shades of the propagated liberal assimilation of the new citizens. There are three main ways that the concept of culture appears in citizenship ceremonies: culture as a key to society, culture as universal human feature, and culture as folkloristic "colouring" of society. I will first present and analyze how each concept is presented at the ceremonies and then discuss how they work together in constructing a welcoming notion of liberal assimilation.

\section{Culture as "the key"}

The first conceptualization of culture at the ceremonies is a metaphoric one. Culture is dealt with as a "key", the nation is accordingly presented as a "house" the new citizens want to inhabit and are supposed to enter. A speaker in Dresden (2009), after talking about the international cultural influences on his hometown, tells his audience:

Furthermore, there is a valuable and actually indispensable access to this country and its people, a sort of general key, and this is its culture. ${ }^{11}$

Presenting the nation as a "house" here has no constructive connotation. The speaker is not talking about a house that can be built, furnished or decorated to the wishes of the new inhabitants. He is instead pointing to the confining character of the walls of the house. To enter, one needs a key. If this key is "culture", it means that new citizens have to somehow acquire the culture of the "house", of the nation and its people. However, this can be achieved in different

\footnotetext{
${ }^{11}$ Darüber hinaus gibt es aber einen wertvollen und eigentlich unverzichtbaren Zugang zu diesem Land und seinen Menschen, eine Art Generalschlüssel, und das ist seine Kultur (guest speaker, Dresden 2009; all translations by the author).
} 
ways. It is not made clear whether the speaker wants the new citizens to fully assimilate to "the culture" of the nation, or whether he is simply encouraging new citizens to cognitively engage with "German culture" in order to make sense of the country and its customs.

At closer view, the concept of culture addressed here has two distinctive elements. It is a universal human feature that people are perceptive to "culture" - or the arts - and therefore the folkloristic colouring of a society can give them an insight into the society in question. Thus, at the citizenship ceremonies, two basic instances of "culture" can be distinguished: culture as a uniting universal human feature, and culture as group property. This second notion, however, is confined to a private, leisurely realm, and as such is not a means of separation but of societal wealth and economic utilization.

\section{Universal culturalism}

The second conceptualization of culture presented at the ceremonies can be characterized as 'universal culturalism'. It is based on the idea that every human being is capable of participating in the perception and practice of art. Thus, "culture" here refers to high-brow culture and fine arts as opposed to folk or popular culture. 'Universal culturalism' is imagined as a common ground for citizenship and belonging that can overrule political, religious, or linguistic divisions. The musicians performing at the ceremonies are an important agent in promoting this conceptualization. Often, they do not only play or sing, but also address the audience and explain the pieces in the program and their meaning:

Ok, a wonderful good evening, as already said, we are playing Wolfgang Amadeus Mozart, er, you will hear why music. Music is a language that is understood everywhere. You are coming here from all over - from everywhere. We are playing a divertimento. The divertimento number three in D major. Divertimento means music in order to amuse oneself (Berlin-Charlottenburg district 2010, trio leader) ${ }^{12}$

In the musician's view, music has a double function at the ceremony. First, it is a common ground for belonging as it "is a language that is understood everywhere". The new citizens are not addressed as cultural "others", but instead as fellow participants in the reception of a classical culture that is perceived as universal. The new and old citizens are thus discursively homogenized on a higher, more global level of 'universal culture'. Second, the trio leader also uses his speech as a moment to teach the audience about classical music: "divertimento means...". This adds a second layer to the function of 'universal cultural belonging'. The emotional understanding of the music forms its basis, but on top there is an intellectual, educational cultivation of the group members.

\footnotetext{
12 Ja einen wunderschönen guten Abend wie schon gesagt wir spielen Wolfgang Amadeus Mozart, äähm, sie werden noch hören warum Musik. Musik ist eine Sprache, die überall verstanden wird. Sie kommen ja von der ganzen- von überall her. Wir spielen ein Divertimento. Das Divertimento Nummer drei in D-Dur. Divertimento bedeutet Musik, um sich zu zerstreuen (trio leader, Charlottenburg 2010).
} 


\section{Culture as folk culture}

The homogenizing function of cultural universalization can also be prominently found in another case from the sample. At a ceremony in Saarbrücken (2010), an international choir is performing. The choir leader explains the group's mission statement, and invites the ceremony guests to join their choir practice "every Tuesday night". When discussing the choir's songs, the conductor says:

Our second song is "Santa Lucia", we have a strong Italian faction in our choir, and of course they enjoy singing their Italian stuff, and of course we enjoy that very much, so we have chosen "Santa Lucia" which is a popular Neapolitan song. ${ }^{13}$

The universal element of culture is presented here as the practice of singing together in the choir. On this basis, differences in national cultural preferences ("their Italian stuff") are not means of real separation. On the basis of a shared cultural practice and choir identity, differences can be treated as personal preferences, and do not hinder the whole choir from enjoying the Italian content "very much" - although it is not clear from the statement whether this refers to the singing of the song or the performance of the "Italian faction".

This treatment of folkloristic immigrant culture as an enrichment for society is a recurring theme at the ceremonies. Another speaker, a new citizen himself, connects it with a critique of assimilation policies:

In my opinion, a complete integration of the immigrants would not be good - and it would be a step towards a monochrome country. Germany needs a trace of exoticism. Otherwise, it would be boring - and, in the long run, unhealthy. ${ }^{14}$

Two metaphoric constructions are interwoven here: The society as "monochrome" versus colourful, and the society as a body that is healthy or not. By connecting "colourful" and "healthy", the "colour" of society and its preservation through time becomes a vital issue. But also, it is associated with a superficial layer of the state of society. One is supposed to "see" whether the city or the societal body is colourful or not, healthy or not. This confines the discussion about cultural assimilation and diversity to a mere superficial level. The wording of the quote analyzed here is a problematic one: depictions of diversity as "colourfulness" and of immigrants as "exotic" are recurrent themes in racial and othering discourses, and they also account for essentializing the "differences" that are promoted here. However, the discourse in the ceremonies treats "colour" and "exoticism" as rather superficial elements in an otherwise culturally integrated society. Assimilation is criticized, but only in relation to "looking alike". As long as "culture" is folk culture, and is not connected to real conflict or structural issues but to beneficial, healthy, interesting "diversity", differences are encouraged. At the same time, however, a common universal "culturalization" is assumed: All citizens and all new citizens are rational, culturalized, enlightened people. By positing the different notions of "culture" on

\footnotetext{
${ }^{13}$ Das zweite, Santa Lucia, wir haben hier im Chor eine starke italienische Fraktion, und die schmettern natürlich gerne ihre italienischen Sachen, und da haben wir natürlich Spaß dran, und haben Santa Lucia gewählt, das ist ein neapolitanisches Volkslied (choir leader, Saarbrücken 2010).

${ }^{14}$ Eine völlige Integration der Immigranten wäre meiner Meinung nach auch nicht gut - und ein Schritt auf dem Weg zu einem monochromen Land. Einen kleinen exotischen Touch braucht Deutschland. Sonst wäre es langweilig - und auf Dauer ungesund (new citizen, Rostock 2012).
} 
different levels of how profoundly they shape the individual and his or her daily life activities, the "culture as a general key" metaphor can ultimately unite the three notions: If new citizens are imagined as modern actors that are perceptive towards "culture", they can use "culture" - in the sense of the arts or of cultural consumption - as a means to cognitively or performatively align themselves with the "culture" they migrate into. The "international choir" introduced above is another significant symbolization of this relation between assimilation and diversity: The immigrant "singers" can continue to sing "their song" - under the premise and on the basis that they are "singers" in the first place.

Correspondingly, at the citizenship ceremonies the hosts tend to present their own culture as universal. For example, European classical music is supposedly understood and listened to everywhere and can thus be used for connecting to the new citizens. On the other hand, the culture of the "others", the new citizens, is understood as folklore, that has its place at the rehearsal of an "international choir" or at a "middle-eastern market", as advertised at the same ceremony in Saarbrücken (2010), when the mayor said during her speech:

On June $19^{\text {th }}$ next week - and I hope that we will meet again then - there will be a middleeastern market arranged there [referring to a specific city quarter] for the first time, and we actually could not manage without the migrants who get involved with this. The "FC Kandel" will look after the soccer tournament, the Islamic congregation has used its network to recruit French marketers, the Romanies' union provides gypsy music and roasted suckling pig, the Turkish students' union invites into its Tavla-Café and also heaps of German marketers and Institutions take part. ${ }^{15}$

In this peculiar combination of different notions of culture, that are positioned at different levels of how they impact individual and social life, and that are differently attributed to the "we" and the "other", the program of liberal assimilation can operate. It merges an underlying cultural assimilation, that is presupposed for the new citizens, with a cultural diversity that is expected to remain on a superficial level, that is economically beneficial but not prone to conflict. In doing so, a demand of assimilation can be discursively evaded or even denied, but can still be implicitly maintained.

\section{Two roots and two notions of culture}

While Joppke (2008) speaks of a "liberal assimilation" as a programmatic idea behind the naturalization procedure at German citizenship ceremonies, liberal subjects are presupposed. New citizens are imagined as compliant with cultural practices like listening to classical music, learning about local history, singing together in a choir, and visiting an "middle-eastern market" where "cultures" are presented as folklore. At the same time, however, they are treated as representatives of some "culture" of their country of origin that is basically confined to the arts,

\footnotetext{
${ }^{15}$ Und dort findet ja auch in der nächsten Woche am 19. Juni, und ich hoffe, dass wir uns dort auch wiedersehen, zum ersten Mal ein orientalischer Markt statt, und da wären wir eigentlich aufgeschmissen ohne die Migrantinnen und Migranten die sich hier engagieren. Der FC Kandel betreut das Fußballturnier, die islamische Gemeinde hat ihre Kontakte spielen lassen um Händler aus Frankreich hierher zu bringen, die Roma-Union steuert Zigeunermusik und gegrilltes Spanferkel bei, der türkische Studentenbund lädt ins Tavla-Cafe ein und jede Menge deutscher Händler und Insti- Institutionen machen dort mit (mayor, Saarbrücken 2010).
} 
but also encompasses clothing or eating habits - things that can be practiced or sold at a market festival. The presentation of new citizens as culturally compatible on a deep individual level can thus be regarded as a revival of the original idea of a Kulturnation, which provided an ideational resource for societal integration in spite of political, religious or language differences.

However, this universalist notion of culture at the ceremonies is complemented with two rather differentialist or folkloristic notions of culture. First, the 'culture as a key' metaphor presents culture as the property of a society. However, culture here does not prevent newcomers from integrating but rather provides a means for cognitively approaching society and its peculiarities. Second, with the folk culture idea "culture" is highlighted as a distinctive feature of the new citizens. Confined to the realm of festivities, meals and hobbies, however, culture here again is not dividing feature. Instead it is compatible to processes, events and structures within society as a whole. Adapting the concept of 'symbolic ethnicity' by Herbert Gans (1979), we can speak of a 'symbolic culture' that is promoted at the ceremonies. Presented in this way, culture does not determine the actions or values of its human carrier, but can be practiced pragmatically. It is confined to the realm of holidays, ceremonies, or ethnic food consumption. Such "culture" is thus a readily available mode for individual distinction, but not a mode for divisively differentiating between groups or even parallel societies within society.

What the speakers do at the citizenship ceremonies is adapting and combining the old ideas of Kulturnation and Bildungsbürgertum into a cultural model that can solve the 'paradox of universalism' stated by Christian Joppke (2008). By taking the existence of a liberal subject for granted, "culture" can become a double instrument of integration rather than separation. It is a common ground - the universal culturalization idea, first formulated with the Kulturnation - and it is a means of playful diversity when it comes to consumption and cultural practice. By universalizing European cultural content and by folklorizing everything else, a "clash of cultures" is discursively averted and also the need for assimilation and for demanding it from the immigrants is prevented. We can thus conclude that the ceremonies do not stand for an assimilationist turn in German citizenship policy. But neither is Germany presented as a multicultural nation. The old idea of Kulturnation is being worked with, is adapted to modern affordances, is revived in its accessible and universalist form rather than in its discarded separationist form.

\section{Conclusion: a modern paradox}

The rhetoric combination of different notions of "culture" represents a strategy whose function can be interpreted on different levels. On the level of my data, the speakers at the ceremonies have to deal with a specific problem: How to depict the new citizens as culturally similar, while still acknowledging that they are somehow different? The strategy they turn to, as I have demonstrated in the analysis of how "culture" is represented at the ceremonies, is to frame the new citizens as somehow different on a superficial level while emphasizing their overall conformity and equality.

This discursive manoeuvre can also, on a more general level, be seen as a discreet introduction of the idea of diversity into public discussion and public opinion about integration in Germany. By differentiating different levels of "culture", what is imagined as "German culture" (but was never 
ultimately defined, see above) can implicitly remain the "guiding culture". It is equated with European culture, with modernity and enlightenment, and is at the same time made invisible by equating it with universal human nature. This move of making it socially invisible is probably what makes it paradoxical. On the other hand, cultural differences can be regarded as superficial, and even beneficial, as colourful, healthy, or interesting.

While one could dismiss this idealistic model of a common cultural ground as purely fictitious, it does have its equivalents in everyday life. They can be found in places where people from different backgrounds live and work together in city quarters or villages, where diversity is treated as an asset rather than a threat, and where cultural differences are perceived as normal elements of modern life. In the end, the "paradox of assimilation" of immigrants leads to the general paradox of modern societies: The paradox of culture(s) that oscillates between integration and differentiation, between conformity and individual freedom, that manifests itself in a myriad of ways - but is also dealt with in a myriad of ways. The discursive differentiation of culture and the positioning of its different elements and notions on different layers, which are also associated with different levels of significance for individual life seems to represent a rather typical way of confronting paradoxes like this. However, it is rarely made as explicit as at the citizenship ceremonies. 


\section{REFERENCES}

Bös, Mathias, and Veronika Schmid. 2012. "Staatsbürgerschaft - ein Auslaufmodell? Zur Dialektik der Konstruktion von Mitgliedschaft in nationalstaatlich verfassten Gesellschaften." In Selbstbeobachtung der modernen Gesellschaft und die neuen Grenzen des Sozialen, ed. Georg Peter and Reuß-Markus Krauße, 53-72. Wiesbaden: Springer.

Brubaker, Rogers. 1992. Citizenship and nationhood in France and Germany. Cambridge: Harvard University Press.

- 2001. "The return of assimilation? Changing perspectives on immigration and its sequels in France, Germany, and the United States." Ethnic and Racial Studies 24(4): 531-48.

Corbin, Juliet, and Anselm Strauss. 2008. Basics of Qualitative Research. Thousand Oaks: Sage.

Damsholt, Tine. 2009. "Ritualizing and Materializing Citizenship." Journal of Ritual Studies 23(2): 17-29.

Faist, Thomas and Triadafilos Triadafilopoulos. 2006. Beyond Nationhood: Citizenship Politics in Germany since Unification. University of Toronto, Munk Centre for International Studies Working Paper No. 1.

Fassin, Didier, and Sarah Mazouz. 2009. "What Is it to Become French? Naturalization as a Republican Rite of Institution." Revue française de sociologie 50(5): 37-64.

Fekete, Liz. 2006. "Enlightened Fundamentalism? Immigration, feminism and the Right." Race and Class 48(2): 1-22.

Gans, Herbert J. 1979. "Symbolic ethnicity: the future of ethnic groups and cultures in America." Ethnic and Racial Studies 2(1): 1-20.

Giesen, Bernhard.1999. Kollektive Identität. Die Intellektuellen und die Nation 2. Frankfurt am Main: Suhrkamp.

Green, Simon. 2000. "Beyond ethnoculturalism? German citizenship in the new millennium." German Politics 9(3): 105-24.

—. 2012. "Much ado about not-very-much? Assessing ten years of German citizenship reform." Citizenship Studies 16(2): 173-88.

Hobsbawm, Eric, and Terence Ranger, eds. 1983. The Invention of Tradition. Cambridge: University Press.

Joppke, Christian. 2007. "State neutrality and Islamic headscarf laws in France and Germany." Theory and Society 36(4): 313-342.

—. 2008. "Immigration and the identity of citizenship: the paradox of universalism." Citizenship Studies 12(6): 533-46.

—. 2010a. "How liberal are citizenship tests?" In How liberal are citizenship tests? EUI Working Paper 
RSCAS 2010/41, ed. Rainer Bauböck and Christian Joppke, 1-4.

—. 2010b. "The inevitable lightening of citizenship." European Journal of Sociology 51(01): 9-32.

Klusmeyer, Douglas. 2001. "A 'guiding culture' for immigrants? Integration and diversity in Germany." Journal of Ethnic and Migration Studies 27(3): 519-532.

Korteweg, Anna, and Gökçe Yurdakul. 2015. The Headscarf Debates. Conflicts of National Belonging. Stanford: Stanford University Press.

Levy, Daniel. 2002. "The Transformation of Germany's Ethno-cultural Idiom: The Case of Ethnic German Immigrants." In Challenging Ethnic Citizenship: German and Israeli Perspectives on Immigration, eds. Daniel Levy and Yfaat Weiss, 221-235. New York, Oxford: Berghahn.

Lithman, Yngve. 2010. "The holistic ambition: Social cohesion and the culturalization of citizenship." Ethnicities 10(4): 488-502.

Maiwald, Kai-Olaf. 2005. "Competence and Praxis: Sequential Analysis in German Sociology." Forum Qualitative Sozialforschung/Forum: Qualitative Social Research 6(3): Art. 31.

Manz, Stefan. 2004. "Constructing a Normative National Identity: The Leitkultur Debate in Germany, 2000/2001." Journal of Multilingual and Multicultural Development 25: 481-96.

Meinecke, Friedrich. 1970 [1908]. Cosmopolitanism and the National State. Translated by Robert B. Kimber. Princeton: University Press.

Merelman, Richard M. 1988. "Cultural displays: An illustration from American immigration." Qualitative Sociology 11(4): 335-54.

Michalowski, Ines. 2011. "Required to assimilate? The content of citizenship tests in five countries." Citizenship Studies 15(6-7): 749-768.

Mouritsen, Per. 2013. "The resilience of citizenship traditions: Civic integration in Germany, Great Britain and Denmark." Ethnicities 13(1): 86-109.

Münkler, Herfried. 2009. Die Deutschen und ihre Mythen. Berlin: Rowohlt.

Oevermann, Ulrich, Tilman Allert, Elisabeth Konau, and Jürgen Krambeck. 1987. "Structures of meaning and objective Hermeneutics." In Modern German Sociology, ed. Volker Meja, Dieter Misgeld, and Nico Stehr, 436-47. New York: Columbia University Press.

Pautz, Hartwig. 2005. "The politics of identity in Germany: the Leitkultur debate." Race \& Class 46(4): 39-52.

Reckwitz, Andreas. 2008. "Die Kontingenzperspektive der 'Kultur'. Kulturbegriffe, Kulturtheorien und das kulturwissenschaftliche Forschungsprogramm." In Unscharfe Grenzen: Perspektiven der Kultursoziologie, ed. Andreas Reckwitz, 15-45. Bielefeld: transcript. 
16 Review of European and Russian Affairs 11 (1), 2017

Schinkel, Willem, and Friso van Houdt. 2010. "The double helix of cultural assimilationism and neoliberalism: citizenship in contemporary governmentality." British Journal of Sociology 61(4): 696-715.

Schmitt, Rudolf. 2005. "Systematic Metaphor Analysis as a Method of Qualitative Research." The Qualitative Report 10(2): 358-94.

Strauss, Anselm. 1996. Qualitative analysis for social scientists. Cambridge: University Press.

Tebble, Adam. 2006. "Exclusion for democracy." Political Theory 34(4): 463-87.

Triadafilopoulos, Triadafilos. 2011. "Illiberal Means to Liberal Ends? Understanding Recent Immigrant Integration Policies in Europe." Journal of Ethnic and Migration Studies 37(6): 861-80.

—. 2012. Becoming Multicultural: Immigration and the Politics of Membership in Canada and Germany. Vancouver/Toronto: UBC.

Verkaaik, Oskar. 2010. "The cachet dilemma. Ritual and agency in new Dutch nationalism." American Ethnologist 37 (1): 69-82 
Published by the Centre for European Studies at Carleton University, Ottawa, Canada Available online at: journals.carleton.ca/rera/index.php/rera

RERA is an electronic academic peer-reviewed journal. Topics relate to the European Union, its Member States, the former Soviet Union, and Central and Eastern Europe. The journal is a joint project supported by the Canada-Europe Transatlantic Dialogue - a cross-Canada research network supported by the Social Sciences and Humanities Research Council of Canada (SSHRC) - along with the Institute of European, Russian and Eurasian Studies (Carleton University) and its associated research unit, the Centre for European Studies.

RERA aims to provide an accessible forum for research, to promote high standards of research and scholarship, and to foster communication among young scholars.

\section{Contact:}

Carleton University

The Centre for European Studies

1103 Dunton Tower

1125 Colonel By Drive

Ottawa, ON K1S 5B6

Canada

Tel: +01 613 520-2600 ext. 3117; E-mail: rera-journal@ carleton.ca

\section{Creative Commons License}

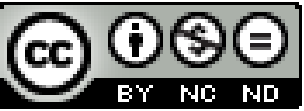

creativecommons.org/licenses/by-nc-nd/3.0

This Working Paper is licensed under a Creative Commons Attribution-Non-CommercialNo Derivs 3.0 Unported License (CC BY-NC-ND 3.0).

Articles appearing in this publication may be freely quoted and reproduced, provided the source is acknowledged. No use of this publication may be made for resale or other commercial purposes.

ISSN: 1718-4835

(C) 2017 The Author(s) 